\title{
Children's Literature and the Internet in the Classroom
}

\author{
Raúl Montero Gilete \\ The Public University of Navarre, Facultad de Ciencias Humanas y Sociales \\ Departamento de Filología y Didáctica de la Lengua \\ Campus de la Arrosadía, Pamplona 31006, Spain
}

Tel: 34-652-716-648Ｅ-mail: raul.montero@unavarra.es

Received: November 22, 2011

Accepted: November 28, $2011 \quad$ Published: December 1, 2011

doi:10.5539/ies.v4n5p47

URL: http://dx.doi.org/10.5539/ies.v4n5p47

\begin{abstract}
The Explorer of the Chest and Golgrim's Keys are two original, unabridged texts integrated in the Scarecrow Project. The project aims at developing ground-breaking methodologies for teaching literature and covers the A2-B2 levels of language competence, both in English and Spanish. The project is based on an integrated use of the Internet (introducing webquests, among other resources), and literature to acquire communicative skills, and it could be easily adapted to the shifting needs of the classroom in Primary, Secondary and University education. It also features original music and artwork, and a great number of exercises for evaluation in different subject areas, as well as for the preparation of official language exams.
\end{abstract}

Keywords: Children's literature, Teaching English, Internet, Scarecrow Project

\section{Introduction}

Spanish teachers' attempts to teach the English language through literature have always been rejected. This fact led Lasagabaster (1999) to question the teachers' belief that they are only competent to teach language, because teaching literature is a more sophisticated task, and presents the dichotomy between language and literature as one with no solid foundations, placing responsibility on the teachers to ask themselves "how they could do best to help their students read texts at a variety of levels of meaning" (p. 8). Nowadays, a new and revolutionary tool has been placed at language instructors' disposal: the Internet. As it happened with literature, however, teachers have a tendency to follow the same pattern and avoid the use of the Internet in the classroom.

Among students, it is not difficult to find voracious consumers both of the Internet and children's literature, particularly books written originally in English which describe other magical lands that both J. R. R. Tolkien and C. S. Lewis created more than half a century ago. Long appreciated as an imaginative writer, C. S. Lewis's "bookish background is a richness of thought, imagination, and writing that has influenced literary criticism, science fiction, children's literature, literary approaches to the Bible, and Christian apologetics throughout the West" (Duriez, 2002, p.48). Lewis's work in particular and literature in general have been used not just as a form of entertainment, but as an effective resource in education. Teachers and educators have the obligation of finding an amusing and modern way to teach and educate language learners, especially young ones. Lorinda Cohoon's (2008) statement in "Serialized Citizenship" points out that

Children are fascinating as political subjects because they represent the values, expectations, and futurity of citizenship, while simultaneously being denied the explicit rights and privileges afforded to adult citizens. They embodied the nation's most sacred ideals, but also mark its boundaries, limitations and exclusions. (p.214)

Our proposal tries to combine the educational benefits of children's literature with the present use of the Internet to teach English as a modern language, because modern times deserve modern strategies.

\section{Scarecrow Project}

\subsection{About the Scarecrow Project}

There was a need of creating a project where students could blend the traditional reading experience with the use of the Internet for learning purposes, incorporating new technologies without forgetting the magic of reading a paper book. To achieve that, the Scarecrow Project was created. The project was developed by the Asociación para el fomento de la educación Portal, a non-profit organization founded in 2009 whose aim is to develop innovative 
methodologies for teaching literature and language, directed, coordinated and developed by Martin Simonson and Raúl Montero Gilete. The Scarecrow project covers the A2-B2 levels of language competence, both in English and Spanish. It is based on an integrated use of the Internet and literature to acquire communicative skills, and it could be easily adapted to the shifting needs of the classroom in Primary, Secondary and University education. It also features original music and artwork, and a great number of exercises for evaluation in different subject areas, and for the preparation of official language exams.

The Scarecrow Project is made up of an original novel and a personal password that provide access to the project's website with a wide range of auxiliary resources. This Teacher's Guide is designed to provide the teacher of each of the subject areas with suggestions for activities related to the project, as well as the necessary tools to fully exploit its vast range of possibilities in their teaching and evaluation. The main aims of this project are to develop the students' reading skills; to stimulate the students to take on an active interest in reading and in literature, as well as an active use of ICT's in the classroom; and to help students become conscious of the learning process related to the acquisition of reading skills.

Each of the novels included in the Scarecrow Project is an original, unabridged text. In other words, it is what a student might find in a bookshop, in the literature section. The design of the book also reinforces its authenticity. It is not created as yet another resource for the classroom; it is a novel which is on sale all over the world, discussed in forums, reviewed in literary magazines and read for pleasure by many different readers in a variety of contexts. For this reason, the students take part in the authentic "life" of the novel, independently of its use in the classroom, and may get information about it from a wide range of sources. As many students tend to develop negative attitudes towards material specifically designed for use in the classroom, this new experience will increase their initial interest in the book, even before they open it. Also, it will give them an opportunity to work with original material in a language different to their own, and so prepare them for what they will find in real contexts, in the real world, outside of school. This is the main reason why the text is not abridged. (Simonson \& Montero, 2009, p.11)

The Scarecrow Project is especially useful in bilingual and trilingual educational centres that use different languages for different subject areas, but it can also be used productively in monolingual educational contexts. As it can also be used with different age groups, in different languages, and in different subjects, different webquests are created for the evaluation of skills in different subjects, or as an extracurricular activity to reinforce the acquisition of contents and skills. Literature was the starting point, and Internet its ally.

\subsection{About the Books}

Since children's literature and the fantasy genre were fundamental for this project, appropriate texts had to be found. An unknown literary saga -The Scarecrow and the Storms- was chosen, because it met the criteria which the project designers had established. This series of books, apart from providing the basis for the activities for the project web page, also constituted literature in itself. It was not an extension of textbooks, and that was why students could approach the school material with the eyes of an enthusiastic reader who was looking for surprising adventures and learning at the same time.

The first book of the saga was Golgrim's Keys. Simonson and Gilete (2009) presented it as the story of

Mirluc, a boy who has had a run of bad luck. His parents have been turned into trees by his jealous aunt Cloudia (who also happens to be a rather unpleasant witch) and he has been sent to live at Castle Grim together with three old men - a doctor, a magician and a cook. As if that wasn't enough, he has just discovered that aunt Cloudia is about to pay him a visit. The only good thing is that aunt Cloudia hates rain - and on the roof of Castle Grim there is a "weather machine". The obvious solution? Press a few buttons. But Mirluc's attempt to deter aunt Cloudia doesn't go entirely to plan. Swept away by the storm he has summoned, Mirluc finds himself journeying through weed-fields, dragon-infested mountains and along a great river in search of his long-lost cousin, Lorenduc, in the hope of setting things right again. Mirluc's adventures also bring to light what seems to be a much larger conspiracy, centring on two mysterious keys. (back cover)

The second book related to the saga was The Explorer of the Chest, translated from Spanish into English by Robert Birch. It recounts the first part of Pantxo's unusual adventures with the Explorers, introducing the young reader to the saga The Scarecrow and the Storms.

One day, Pantxo opens an old chest in the attic. To his amazement, he discovers that there are many things inside the chest that his father left him before he died. As he rummages around and looks at the objects, he begins to remember everything he used to do with his father. Little by little, Pantxo realises that there is 
more inside that chest than just gadgets - a whole world is actually coming to life before his astonished eyes. However, before he reaches the bottom of the chest, there is an even bigger surprise waiting for him ... (Gilete, 2010, back cover).

Lionel Gossman (1981) put forward that "both the teaching of literature in colleges and universities and the category of literature itself, as we know them, are of fairly recent date, not much more than a century old" (p.341), so trying to introduce English literature in the classroom in a non-Anglo-Saxon environment seemed really difficult. There had been some teachers who had successfully implemented the idea of working with children's literature in the education of young adult EFL (English as a Foreign Language) learners, while covering a syllabus focused on reading, speaking, listening and writing, and practising vocabulary, grammar and phonetics, as Lahina Ho (2000), among many others, did with her Chinese adult learners. In the conclusions of her research, she stated that

[C]hildren's literature works well with adult students because it is intellectually stimulating, encouragingly readable, linguistically challenging, literarily fulfilling, and educationally rewarding. The use of children's literature may be limited as it cannot be used for all language skills instruction; neither can it be effective all the time as the protagonists are children and identification for adult readers is difficult... Finally, children's literature takes on a new perspective as it can be enjoyed by adult learners, and it can expose them to a new world of education. (pp.269-270)

Her study concluded that using children's literature could be effective with other students from countries where English is a foreign language, which provided the reassurance of previous positive experiences.

\subsection{About the Use of the Internet in Education}

Experiences like Gossman's were not new at all, but it was necessary to introduce something new. Students from seven to fourteen years old were asked about their daily preferences and it was confirmed that young learners in general loved using computers, video-games, and almost everything related to technology, so integrating the Internet into the project seemed a must.

Buchman and Funk (1996) documented game playing behavior of 900 fourth- through eighth-grade children and found approximately $90 \%$ of fourth graders reported playing one or more hours each week on computer games. This 1990 study pre-dates active, voluntary involvement of youth on console-based games at home. Harris (1999) found $85 \%$ of the time students spent in voluntary use of computers in the home was spent on games and adventures. Mumtaz's (2001) more recent study found that $85 \%$ of children enjoyed playing computer games on their home computer, demonstrating more satisfaction with home computer use than school computer use, where computers were more frequently associated with tasks than with play. (Chamberlin, 2003, p.16)

Looking for previous accounts of the use of the Internet in education, a well-documented study carried out by the Pew Internet and American Life Project in Washington D.C. was found. The authors of the article, Amanda Lenhart, Maya Simon and Mike Graziano (2001), exposed that

[T]eenagers use the Internet as an essential study aid outside the classroom and that the Internet increasingly has a place inside the classroom. Findings from a survey of 754 youths aged 12-17 conducted in November and December 2000 include: 94\% who have Internet access say they use the Internet for school research, and 78\% say they believe the Internet helps them with schoolwork (p. 1).

Out of our secondary school students in Virgen Niña School, Vitoria-Gasteiz (Spain), in 2006, 98\% used the Internet for school research, and nowadays, four years later, almost all our English students from the Degree in Infant and Primary Education at the Public University of Navarre use the Internet. Moreover, in the 2009-10 academic year, the Spanish Government started the School 2.0. Programme (Programa Escuela 2.0) whose aim was to integrate Information and Communication Technologies (ICT) into educational centres. Its objective is that every pupil who is studying in a state school uses a laptop computer for study. Last year, students in their fifth year of Primary school (10 years old) were the first ones to use the programme. This academic year, the programme will cover fifth and sixth grade; next year, the first year of Secondary school; and in two years' time, the second year (13 years old). The programme is meant to be the starting point for the digital classroom era, which incorporates Internet connectivity, so the Internet and ICTs are presented as a reality in the classroom and a means for a fundamental change in the manner in which students learn and retain knowledge. In his article about online education, Rudy Hirschheim (2005) concludes that

[W] hile students taking Internet courses get the same degree and grades similar to those taking the course in a classroom, they also want a more interesting mix of Internet and traditional elements within the same course; their educational issues addressed; group work revaluated, mostly individual tasks; more tightly 
structured courses, with all teaching materials delivered online; and a new relationship with the professor. (p.101)

\section{An Example of How to Use the Scarecrow Project's Webquest in the Classroom}

The Internet appears as an opportunity for the future in education, but both teachers and students often find it difficult to locate the information they need. There are several ways of presenting activities to the students, but webquests are particularly attractive. Jeremy Harmer (2007) defines a webquest as

[A] particular type of information which is provided by a kind of (Internet-based) extended project called a webquest. This employs Internet resources for students to use for researching, but rather than have students search on the Internet for themselves, in a webquest the teacher has prepared an introduction and then given students "clickable" sites to visit. (p. 191).

The following two webquests are part of the project and they serve as an example of how students can apply what they have read and learned in the novels, while using the Internet and studying different subjects. The first webquest was designed by Martin Simonson (Webquest1) and it can be used in English, Arts and Crafts, Computer Science, and Literature. It uses the novel Golgrim's Keys as support for the activities presented throughout the webquest. The second webquest presented in this article was designed by Artur Kocialkowski (Webquest2). The author uses the other novel presented at the very beginning, The Explorer of the Chest, as the basis for covering different subjects such as English, History, Computer Science, and Literature.

In the Introduction phase of the Webquest1, students are told about the topic of the webquest, the different trends in fantasy art over the last 150 years. Questions such as What are the roots of fantasy art? What are the typical themes and styles used for illustration of the fantastic? are posed. Then, the student will be asked to compare certain aspects of it with the artwork made by Anke Eissmann for the fantasy trilogy The Scarecrow and the Storms.

In the Introduction phase of the Webquest2, students are also told about the topic of the webquest, which is going to be focused on the different types of children's literature in general, and fantasy literature in particular. Students will find information on this type of literature so as to later be able to relate it with the novel The Explorer of the Chest.

In the Online resources phase, students are told that they must investigate the resources listed below in the form of links to a number of webpages. They have been selected as clickable sites to visit for the student. Webquest1 is centred on $19^{\text {th }}$-century art and $20^{\text {th }}$-century fantasy art. In the first part, students must look for information on $19^{\text {th }}$-century art. The listed external links are related to the Hudson River School, Pre-Raphaelites and the Romantic Landscape Painting, while adding one example for each movement: Albert Bierstadt, Sir Edward Coley Burne-Jones and Caspar David Friedrich. The second part is focused on both early and late $20^{\text {th }}$-century fantasy art and students are required to find information related to book illustrators such as John Bauer, Kay Nielsen, John Howe, Alan Lee, Anke Eissmann and Ted Nasmith.

In Webquest2, the Online resources explore children's literature in general and Anglo-Saxon children's literature in the first half of $20^{\text {th }}$ century in particular, focusing on Baum's The Wonderful Wizard of Oz (1900), Barrie's Peter Pan and Wendy (1911) and Lewis's The Chronicles of Narnia (1950-1956).

In the Assignment phase, several questions are presented. Those questions can be answered after a proper reading of the information given in the Online resources phase, so that students review and internalize what they have read. Webquest 1 is divided in two parts. The first one presents three general questions that students have to answer:

a) Can you find any art from the $19^{\text {th }}$ century that is similar to the works of modern fantasy artist? Give two examples and explain the similarities with reference to technique, style, settings, moods, and themes.

b) What modern fantasy illustrators are closest in style, theme, mood and composition to the illustrations of Anke Eissmann related to the work of J. R. R. Tolkien? Give examples and explain why you think they are similar.

c) Compare this picture by Anke Eissmann (Simonson \& Gilete, 2009, cover for Book of Adventure) with "A Song in the Trollshaws", by Ted Nasmith. Analyse the differences in style, tone, setting, composition and use of colour. What makes the two illustrations so different in mood?

After the completion of part 1, part 2 asks students to practise their drawing skills based on the previously read theory and their personal preferences. They have to look at three pictures and read the text that accompanies each of them, taken from the novel Golgrim's Keys. Then, they have to choose one and draw/colour an alternative version and justify their changes in style, tone, mood and technique with references to the text. 
Webquest 2 is also divided in two parts. The first one presents three general questions about what children's literature is, to what literary genre The Explorer of the Chest belongs, and what other fantasy genre is similar to The Explorer of the Chest and how similar it is providing at least two examples. The second part of the assignment asks students to elaborate an essay or a short story to reinforce their writing skills based on the following passage from the book:

And with a leap, papa was up on the wall and then helped me up, too. Then we jumped down inside the walls. Everything smelled of roses. I gripped papa's hand and we began to walk. In my mind I just kept on saying hi to all the dead people and imagining that they were lying there all happy and content. In the end, papa stopped in front of a tomb. We stayed there for quite a few minutes, and then just before leaving, papa whispered: "Rest in peace, my dear Cristian". (Gilete, 2010, p.47).

In the Formal instructions phase, apart from explaining the task itself, there are also rules on the format in which the task must be presented. Every time they do a task, the students have to follow a specific style sheet in order to demonstrate their ability to use other tools related to Computer Science. They also have to download the style sheet in a pdf document. This phase is common for the two webquests.

Finally, the last phase in the Scarecrow Project webquest is the Contest phase, where students, apart from being evaluated by their teachers, have the opportunity to participate in a contest related to the novels. There are two types of contest, the literary contest and the drawing contest. This is another way of motivating students by showing them that the efforts made in class are not just for the class, but can be enjoyed by anyone who is interested in the novels. They can also become the first literary critic or artist in doing something related to the stories of Mirluc or Pantxo.

As Harmer (2007) states,

[T] he point about webquests is that the Internet research is a stage towards some other goal (in our case an essay or a drawing). And, thanks to the wealth of material available on the Internet, students can do significant research (including text, music, pictures...) at a computer screen rather than having to go to a library. (p.192)

\section{Conclusion}

In general, teachers and students who have experimented with this project during the last academic year (2009-10) find it very attractive. Both Golgrim's Keys and The Explorer of the Chest are writings of a child, and both of them try to add something new to literature and education. Moreover, it has also been suggested that the project should include more novels and cover other language levels, a need which will be addressed with more titles in the future.

To return to the opening objective and the necessity for creating a new proposal for the incorporation of children's literature and the Internet in students' daily life, it is clear that there is a lot of work to do, but at least, this project presents a real alternative. It is very encouraging to see that both teachers and students are glad to participate in the Scarecrow Project and how some colleagues from other schools and universities in other countries want to know more and ask for its introduction in the learning of Second Languages at Primary, Secondary and University levels. The use of children's literature and the Internet in the classroom can significantly contribute to the development of language skills while helping our students with valuable positive behavior patterns. Further studies will present more specific data and might show new applications of the project in education.

\section{References}

Chamberlin, B. (2003). Creating entertaining games with educational content: Case studies of user experiences with the children's website, food detectives fight bac! Dissertation, USA: University of Virginia. [Online] Available: http://aces.nmsu.edu/bchamberlin/dissertation/Dissertation_sm_ims.doc (October 30, 2011)

Cohoon, L. (2008). The child as (potential) citizen. In Children's literature. England: Hollins University.

Coyle, D. (2009). Foreword. CLIL across educational levels. Spain: Santillana Educación \& Richmond Publishing.

Duriez, C. (2002). The C. S. Lewis encyclopedia. Great Britain: Azure.

Gilete, R. M. (2010). The explorer of the chest, translated by Robert Birch. Spain: PortalEditions.

Gossman, L. (1981). Literature and Education. New Literary History, 13 (2). USA: The University of Virginia. [Online] Available: http://www.jstor.org/pps/468916 (October 30, 2011)

Harmer, J. (2007). The practice of English language teaching. England: Pearson Education Limited.

Hirschheim, R. (2005). The Internet-Based Education Bandwagon: Look Before You Leap. Communications of the $A C M, 48$ (7). USA: ACM. [Online] Available: http://portal.acm.org/citation.cfm?id=1070844 (October 30, 2011) 
Ho, L. (2000). Children's Literature in Adult Education. Children's Literature in Education, 31 (4). USA: Human Science Press. [Online] Available: http://www.springerlink.com/content/m44821w838132151/ (October 30, 2011)

Lenhart, A., Simon, M., \& Graziano, M. (2001). The Internet and Education: Findings of the Pew Internet \& American Life Project. Washington: Pew Internet \& American Life Project. [Online] Available: http://pewinternet.org/reports/toc.asp?Report=39 (October 30, 2011)

Mehisto, P., Marsh, D., \& Frigols M. J. (2008). Uncovering CLIL. Content and language integrated learning in bilingual and multilingual education. England: Macmillan Published Limited.

Montero Gilete, R., Simonson, M. (Coords.), \& Kocialkowski, A. (2010). Scarecrow project teacher's guide - The explorer of the chest. Spain: PortalEditions.

Simonson, M., \& Gilete, R. M. (2009). Golgrim's keys. Spain: PortalEditions.

Simonson, M., \& Gilete, R. M. (2009). Golgrim's keys - Book of adventure. Spain: PortalEditions.

Simonson, M., \& Montero, R. (2009). Scarecrow project teacher's guide - Golgrim's keys. Spain: PortalEditions. 